\section{The crisis of} 'multiculturalism' in Europe: Mediated minarets, intolerable subjects
European Journal of Cultural Studies 15(2) 123-138 - The Author(s) 2012 Reprints and permission: sagepub. co.uk/journalsPermissions.nav DOI: $10.1177 / 1367549411432384$ ecs.sagepub.com

(S)SGE

\author{
Alana Lentin \\ University of Sussex, UK

\section{Gavan Titley} \\ National University of Ireland, Ireland
}

\begin{abstract}
During the last decade, European countries have declared a 'crisis' of multiculturalism. This crisis has gained significant political traction, despite the empirical absence of a failed experiment with multiculturalism. This introduction focuses on the narrative of multicultural backlash, which purports that 'parallel societies' and 'intolerable subjects' and practices have been allowed to flourish within European societies. Beyond particular contexts, the problem of intolerable subjects is seen as a shared European challenge, requiring disintegrated migrants and Muslim populations to display loyalty, adopt 'our' values, and prove the legitimacy of their belonging. This introduction critiques multicultural backlash, less as a rejection of piecemeal multicultural policies than as a denial of lived multiculture. This is developed through an examination of racism in a post-racial era, and by analysing the ways in which integrationist projects further embed culturalist ontology.
\end{abstract}

\title{
Keywords
}

anti-racism, culturalism, culture, Europe, integration, mediation, multiculturalism, post-race, racism

\section{Corresponding author:}

Gavan Titley, Centre for Media Studies, Arts Buil ding, National University of Ireland, Maynooth, Co. Kildare, Ireland.

Email: gavan.titley@nuim.ie 


\section{One world, our culture, no race}

The idea of 'one world', Alain Badiou argues in The Meaning of Sarkozy (2008), is a performative invitation. Its potential performativity rescues it, as a philosophical idea, from humanitarian rhetoric and the sing-along choruses of charity records and restores a transformative sense, albeit one where a beguiling simplicity quickly gives way to demanding implications. As opposed to a vision of 'one world' achieved through the hopeful transcendence of difference, for Badiou, difference is the 'transcendental' of the world, its immanent principle of unity. As a consequence, he writes, what this world 'cannot have is subjective or "cultural" preconditions for existence within it' (2008: 63). What Badiou is writing against in part is the sustained application of cultural preconditions to the contingent legitimacy of post-colonial and minoritized French citizens and inhabitants, consistently called upon to symbolically prove their integratedness: by removing the veil in public space, professing their 'love for France' (Badiou, 2008: 62-63) and, at the time of writing, accepting the 'incompatibility' of the burka with 'French values' - worn by anything between 367 and 2000 French women, but of key symbolic import in the Grand Débat sur l'Identité Nationale conducted in 2009-10 (Bohlen, 2009).

As a long-term activist in migrant solidarity, no doubt Badiou is aware of the ways in which a cultural politics of 'our world' has been refined and adapted from the antiimmigration politics of France and other European countries. As Liz Fekete writes, in a discussion of mainstream political acquiesc ence in xenophobia in the 1990s, 'Once structures of exclusion are erected for one group in society, they can easily be adapted for others' (2009: 9). The racialized, 'non-western' poor, held politically responsible for the systemic changes of neoliberal globalization to European labour markets in the 1990 s, have been fused with suspect Muslim 'communities' since September 2001. Culturally unassimilated, ideologically unassimilable and transnationally implicated in disloyalty, the 'racial politics of the War on Terror' (Pitcher, 2009: 7) has produced 'intolerable subjects'. Their presence, legitimacy and, frequently, rights depend on satisfying a mass of cultural preconditions which involve the imposition of prohibitions: on forms of dress, religious symbols, marriage partners and 'unacceptable behaviours' (McGhee, 2008). They also involve performative compulsions to allegiance through citizenship, loyalty and integration tests and ceremonies. Thus Badiou's insistence on 'one world' is in part a reaction to a new 'politics of recognition' in Europe: the requirement to be recognized as 'deserving', 'moderate' and 'integrated' - or at least as not dis-integrated and dis-integrating.

The allusion to Charles Taylor's (1992) widely cited discussion of multicultural recognition is more than convention. The further context of Badiou's contention is the emergent consensus in Western Europe that preconditions are not only necessary to govern suspect populations, but that they are made imperative by their wilful neglect in a past era of multicultural hegemony. At least analytically, multiculturalism is anything but a stable object. It is, as Charles W. Mills writes, a 'conceptual grab bag' of issues relating to 'race', culture and identity that 'seems to be defined simply by negation - whatever does not fit into the "traditional" political map of, say, the 1950s is stuffed in here' (2007: 89). While the multivalent, normative critique of multiculturalism has recently produced some interesting attempts at philosophical and political reconstruction (Phillips, 2007), the reach and opacity of 'multicultural ism' has prompted an interest in conjunctural analysis: what do discourses 
of multiculturalism reveal about shifting questions of 'race', nationhood, state, gender, class, identity and globalization (Gunew, 2004; McGhee, 2008; Pitcher, 2009; Schuster and Solomos, 2001)?

This special issue takes a related approach and examines, in and through different contexts, how a concerted backlash against 'multiculturalism' and its over-tolerated subjects shapes emergent forms of state and popular racism in Europe. Analysis may approach multiculturalism as a confused and fecund discursive space, yet in contemporary public debate multiculturalism was and has a discursive cohesiveness that compels the corrective conditionalities of the post-multicultural era. The project that generated this special issue initially focused on how a trans-European narrative of multicultural 'mismanagement' has become so profoundly implicated in stories of the present, and on how an 'unapologetic' demand for compensatory conditionalities, gestures and restrictions was made towards the racialized. That this narrative is comparable in nation-states with internally complex and contradictory histories of multicultural policy and rhetoric, and also in states with very recent histories of multivalent migration, prompted an ancillary focus on the transnational mediation of multicultural crisis - or, what European 'elsewheres' tell 'us' about our national 'here'. The mediation of crisis is discussed in the next section and developed by focusing heuristically on the recent symbolic flashpoint of minaret construction in Switzerland.

If the multicultural crisis is mediated, arguably it is also mediating - a conduit for what Goldberg (2009) terms 'racial Europeanization', expressed through the delineation of reanimated European universalism in contradistinction to the irreducible difference of Islam and non-western Others, and through the article of faith that such essentialism and exclusion cannot be thought of as racist. By understanding the range of sociocultural ills for which multicultural ism is supposedly culpable, we can begin to examine why a resurgence of racism is made possible by a post-racial focus on issues of culture, and this question is taken up in a subsequent section.

\section{The rejection of multiculturalism}

According to Christopher Caldwell, in his widely publicized book Reflections on the Revolution in Europe (2009), multicultural ism has derogated from the 'essence of Europe' and 'requires the sacrifice of liberties that natives once thought of as rights' (2009: 11). ${ }^{1}$ Caldwell's account is an ordinary rendition of multiculturalism's supposed genesis, an 'experiment' shaped by cosmopolitan elites in response to demands for cultural recognition from assertive minorities.

The 'multicultural fantasy in Europe' (Rieff, 2005) is held to have valorized difference over commonal ity, cultural particularity over social cohesion, and an apologetic relativism at the expense of shared values. As Arun Kundnani points out in this issue, the assertion of common values interweaves conservative, exclusivist invocations of national integrity and Christian heritage, and also an expansive 'liberalism' concerned with reclaiming and extending 'our' Enlightenment on the field of equality, gender and sexuality. Confronted with the creation of 'parallel societies', with diverse, suspect migrant and minority 'communities' that do not share our way of life - and in the case of Muslims, who may even be its enemies - and with cultural-demographic challenges to 'national cultures', Europe, as Flemming Rose of Jyllands-Posten argues, must confront 
... unpleasant realities about Europe's failed experiment with multiculturalism. It's time for the Old Continent to face facts and make some profound changes in its outlook on immigration, integration and the coming Muslim demographic surge. After decades of appeasement and political correctness, combined with growing fear of a radical minority prepared to comm it serious violence, Europe's moment of truth is here. Europe today finds itself trapped in a posture of moral relativism that is undermining its liberal values. An unholy three-cornered alliance between Middle Eastern dictators, radical imams who live in Europe and Europe's traditional left-wing is establishing a politics of victimology. (quoted in Rose, 2006: 13)

While Rose's condensed version of the narrative of crisis has much in common with the alarmist tones of what Pankaj Mishra (2009) has termed 'Eurabia-mongers', its substantive shape is widely circulated in states with established - if troubled and complex - practices of multicultural rhetoric and policy, such as the Netherlands and the UK; in a France that burnishes laïcité against any hint of particularist taint; and in recent migration societies such as Finland and Ireland, determined to 'get it right' and bypass this era of troubled experimentation. Multicultural experimentation suggests a temporary deviation from the 'essence' and this sense of an experiment having gone too far is inscribed in the discourse of correction - 'no more apologies' (see Hervik in this issue), no more opportunities to 'abuse our multicultural love' (Ahmed, 2008: 3). Cultural preconditions have been instigated as dimensions of the turn to integration and as several contributions here document, the insistence on forced acculturation in integration governance has much to do with the measures being conceived of as undoing the damage of multicultural indulgence. It is in the name of integration that ever-increasing and always-shifting 'cultural preconditions' on citizenship and legitimate belonging are being articulated and enforced - as well as other strategies of control through anti-terror legislation (Kundnani, 2007), the linking of immigration reform to questions of 'acceptable behaviour' and 'speech crime' (Fekete, 2009; McGhee, 2008), and modes of regulation and scrutiny that Les Back and Shamser Sinha discuss as 'moving checkpoints' in this issue.

This special issue does not set out to document the empirical, political and theoretical elisions and problems with this widely circulated sense of multiculturalism as a delineable era. As several contributions here discuss, the precepts, assumptions and infer ences of crisis thinking are historically and empirically suspect, and they are not amenable to empirical rebuttal. Instead, this issue seeks to question the contours of multicultural crisis and postmulticultural consensus in a number of ways. It starts by approaching the rejection of multiculturalism as an anxious rejection of the very fact of multiculture, not the piecemeal complex of the multicultural policies and initiatives developed to manage it. Thus the contemporary politics of cultural correction must be resituated in an understanding of racism in a post-racial era. Undoing the relativist experiment and asserting the new realism of cultural incompatibility and hierarchy is based on an assumption that when 'race' and racism were exclusively linked to skin colour and phenotype, they were historical aberrations, largely expunged from what Tony Judt (2009) calls the 'sunlit uplands' of a present consumed by memorialization and ahistorical exceptionality. As this introduction argues, it is the historical reduction of anti-racist politics to questions of cultural recognition and the excision of 'race' as a political category in favour of culture, that makes possible the claim from various political positions that we are post-race. However, historically 'race' 
and racism, and culture and culturalism, have been profoundly intertwined (Balibar, 1991; MacMaster, 2001). As Caldwell writes: 'If you understand how immigration, Islam and native European culture interact in any Western European country, you can predict roughly how they will interact in any other' (2009: 19). Islam as Muslims and immigrants, in but not of Europe, produc ing through their essential and transposable alien character a European homogeneity predicated on their status as constitutive outsiders, inside; this is the work of 'race' in a context of official racelessness. As David Theo Goldberg suggests:

Europe begins to exemplify what happens when no category is available to name a set of experiences that are linked in their production or at least inflection, historically and symbolically, experientially and politically, to racial arrangements and engagements. (2009:154)

If culture works as a categorical substitute for disavowed 'race' while re-avowing the salience of 'race-thinking', this salience is symptomatic of a wider ontology. The insistence on core values and cultural discipline in integration discourses does not suggest a rejection of multiculturalism, but rather its recalibration. In other words, the problem is not culture but an excess of (their) culture. That political problems shaped by geopolitical confl ict, neoliberal transformation and attendant human mobility should be understood primarily as cultural and requiring cultural solutions, suggests that the crisis of multiculturalism is symptomatic rather than causal. It is a manifestation of what George Yúdice (2003) argues is the accretion of governmental power to culture as the dominant framework for under standing and responding to problems of power that were once considered political. As we argue in conclusion, this culturalization of politics is manifested in how solutions proposed for the cultural excess of multicultural failure are, in themselves, culturally over-determined.

\section{Mediating crisis, reciting truths}

Commenting on the pan-European coverage of the 2009 Swiss referendum on minaret construction, Nilüfer Göle (2010) notes how 'the debate on the minarets in particular and the visibility of Islam in general, generates transnational dynamics and assemblages of disparate elements'. ${ }^{2}$ While national identity debates have been frequently shaped by readings of national controversies (Fekete, 2009; McGhee, 2008), multiculturalism debates have coalesced latterly around European reference points. If $9 / 11$ provides a conventional and misleading point of geopolitical rupture and narrative departure - a point from which, as Derek Gregory writes, 'the metropolis exercised its customary privilege to inspect the rest of the world' (2004: 21) - a subsequent series of iconic events in Western Europe have assumed explanatory power in relation to diverse and often particularized political conflicts. The murder of Theo Van Gogh in Amsterdam in 2004, the terrorist attacks in Madrid in 2004 and London in 2005, the uprisings in Clichy-sous-Bois in Paris the same year, the Jyllands-Posten 'cartoon controversy' in 2005-06: these and other symbolic flashpoints are widely regarded as evidence of a shared European crisis and salutary lessons in a collective process of political reorientation. The 'minaret debate' in 2009 has been the latest symbolic contest of transnational resonance to be added to this list. It is at least in part because of these insistent assemblages that we have approached this crisis as a mediated crisis. As Sonia Livingstone points out, to speak of a mediated phenomenon 
is to do more than make banal reference to the penetration and ubiquity of media coverage; it is to claim that the phenomenon in question is 'transformed, reconstituted, by contemporary processes of mediation' (2009:2). In what ways, then, is the crisis of mult iculturalism constituted by mediation?

At one level, the 'transnational dynamics and assemblages of disparate elements' discussed by Göle indicate an acceleration of established processes of news 'domestication' (Nossek, 2004). Spectacular events are intensively mediated, and their mediation occurs across interlocking scales and forms: in a continuous real-time news environment, stories are never complete - they roll on, 'piggyback' on related stories and sources from multiple platforms and invite ongoing and near-instantaneous comment to unpack their meaning, at national and European levels. Moreover, in a changing political economy of news - or, more news with fewer resources - production looks to repertoires of established reference to provide immediate and often contingent context for a story (Fenton, 2009). Transnational assemblages are also a consequence of the horizontal networking of information in an expansive mediascape of dense interconnection. As Eide et al. write in relation to the Muhammed cartoons as a transnational media event, 'new, fast, intense and potentially less controllable media realities' were central to the global accretion of forms and sites of conflict to the 'controversy' (2008: 21).

Eide et al. argue against positioning the cartoons in any 'one global discursive situation', and this attention to positionality, polysemy and remediation is basic to recent theorizations of global mediaspace (Schlesinger, 2009; Silverstone, 2007). In this context, the assemblages of an insistent 'narrative' of multicultural crisis and corrective integrationism are striking and require explanation. To this end it is useful to return to an earlier exploration of mediation. In The Practice of Everyday Life, Michel De Certeau examines the assembly of social orthodoxies: 'Society has become a recited society in three senses; it is defined by stories (récits, the fables constituted by our advertising and informational media), by citations of stories and by the interminable recitation of stories' (1986: 186). For De Certeau, recitation involves the production of social facts through narrativization and repetition, facts which then appear unconstructed by anyone and where, amid a 'forest of narrativities ... stories have a providential and predestining function' (1986: 186). In this argument, recurrent assemblages beat a path through this forest, and the invocation of crisis has become a process of recitation, framing (predestining) events and varied, antagonistic social processes within a unifying, teleological and ult imately self-affirming narrative of visions of Muslim/ migrant disintegratedness and multicultural collapse. However, recitation is not only a product of media-centric mediation and the 'fables' produced under the conditions discussed; it is a product of intertwining forms of mediation and the beliefs that constitute them. This is now explored in the heuristic example of the Swiss minaret referendum.

On 29 November 2009 , the Swiss electorate voted by a majority of 57.5 percent for a constitutional amendment to ban the construction of minarets. The referendum was organized by the Swiss People's Party and the Federal Democratic Union. At the time of the vote, four minarets existed in the country, prohibited by environmental legislation from broadcasting a call to prayer. Nevertheless this new cultural precondition is necessary, according to Ulrich Schlüer, a Swiss People's Party member of parliament, to prevent a particular kind of domino effect: 
The fear is great that the minarets will be followed by the calls to prayer of the muezzin ... Sharia is gaining in importance in Switzerland and in Europe. That means honour killings, forced marriages, circumcision, wearing the burka, ignoring school rules and even stoning. (Traynor, 2009)

While the Swiss People's Party was briefly infamous for its anti-immigrant 'Sicherheit schaffen' ('Achieve Security') campaign in 2007, the idea of intervening in a process of path-dependent Islamicization was widely reported as also mobilizing a liberal defence of secularism and feminist support for a stand against the oppression of women (Campbell, 2009).

In its very inception, the referendum was conceived of and calibrated as a media event, emerging from a wider search for a point of symbolic controversy designed to mediate anti-immigrant discontent through a cipher of Muslim disintegratedness. As Tariq Ramadan (2009) reported on polling day, targeting traditional methods of animal slaughter had been initially proposed, until the potential implications of this for the Swiss Jewish population were realized. Thus despite the mechanics of direct democracy, the referendum displayed a 'market research' agenda-setting, high-impact imagery and 'appeal to identity based on hostility to immigrants' that Colin Crouch (2004: 19) discusses as symptoms of postdemocracy. It also recalls a broader political strategy. As Peter Hervik outlines in this issue, the overt cultural chauvinism of much public discourse in Denmark has been influenced by media-led, mock plebiscites on the presence of immigrants in Denmark - staged events which have supported the recurrent push by the Danish People's Party for a referendum examining the country's future as a 'multi-ethnic society'. This political synchronization is context-specific, but it does point to the widespread role of media actors as overt actors in crisis debates (Titley, 2009) and, as Hervik argues elsewhere, illustrates a crucial pre-history to the 'entirely media-created' Jyllands-Posten cartoon affair (Boe and Hervik, 2008). Such approaches position the instigators as mediators between an anxious, major ity-ethnic population, and the invariably 'politically correct' elites that repress 'honest and open debates' on immigration.

Minarets are the new veils: symbolic, multicultural controversies involving images and practices taken as a priori evidence of parallelism and the alien within, and combining both a delineable 'issue' with mobile suggestiveness. The minaret is a lightning conductor, but also a weapon, connoting expansionism and war and a phallus pointing back at the Muslim repression of women. The impetus for the referendum came from the far and conservative Right, yet like the veil the minaret is implicated in wider faultlines concerning 'integration' and security, gender equality, the character of liberal democracy and the public presence of religion. Such symbolic controversies have not only variegated resonance across the conventional political spectrum, as discussed below, but are recitations that imagine the nation through the European collective. Within days of the referendum, Daniel Pipes (2010) could write in The Jerusalem Post about 'European resistance to Islamicization' with reference to a plethora of online polls by national media in Europe, as well as a smaller number of opinion polls. ${ }^{3}$ These inhabited a spectrum from faithful domestication of the Swiss question to such variations as the construction of Mosques, anxiety concerning 'Islamicization' and the process of immigrant integration.

It is this fluidity of appropriation and translation that betrays the deeper grammar of assemblage. If the minaret controversy rapidly became a transnational citation, its mobility 
is also a function of its succinct compression of dominant, binary tropes and mythologies of Europe and Islam: secular and superstitious, enlightened and endarkened, liberal and communitarian, tolerant and intolerant, declining and virile. While the rhetoric of a 'slippery slope' towards Islamicization was articulated from Left and Right, some coverage of the referendum drew attention to the gap between this projection and the often secular, predominantly Balkan-European background of the Swiss Muslim population. In keeping with crisis dynamics, this lived reality is not the point. The referent is not the particular population, but the transposable Muslims of Caldwell's imagination - or what Goldberg calls the 'idea of the Muslim', the deterritorialized - and assertively re-territorializing wraith of the 'War on Terror':

The Muslim in Europe - not individual Muslims, not even Muslim communities, but the idea of the Muslim himself - has come to represent the threat of death ... The Muslim image in contemporary Europe is overwhelmingly one of fanaticism, fundamentalism, female (women and girls') suppression, subjugation and repression. The Muslim in this view foments conflict ... He is a traditionalist, premodern, in the tradition of racial historicism difficult if not impossible to modernize, at least without ceasing to be 'the Muslim'. (2009: 165-166; emphasis in original)

If there is an empirical gap between the actual and the transposed, it is not so much a reality check as a time lag in the teleology of disintegratedness. In other words, as the commentator Anne Applebaum argues, the referendum was a prophylactic measure:

As I say, there is very little evidence that separatist, politically extreme Islam is growing rapidly in Switzerland. However the Swiss read newspapers and they watch television. And in recent years politically extreme forms of Islam have indeed emerged in every European country with a large Muslim population ... th ink of the London transportation bombings, the Span ish tra in bombs, the murder of Dutch film director Theo Van Gogh ... noone quite says what the real issue is, but everybody knows: as grotesquely unfair as a referendum may have been to hundreds of thousands of ord inary, well integrated Muslims, I've no doubt that the Swiss voted in favor primarily because they don 't have much Islamic extremism - and they don't want any, either. (Applebaum, 2010)

Recitation as predestination, as Maria Stehle notes in this issue and elsewhere (Stehle, 2006): this essential transposability shaped German media coverage of the uprisings in Parisian suburbs in 2005 , seen as inevitably prefiguring future violent foment in the immigrant 'ghettos' of German cities. As Stehle argues, the ghetto functions as an 'internal borderland', needed and feared, the evidence of dis-integration that hinders a tantalising completeness. However, if the irreducibility of figurative Muslims signifies a societal lack, Islam, as Goldberg argues, 'is taken in the dominant European imaginary to represent a collection of lacks' (2009: 165), and as such contrasts with a European identity made whole by the universalism of shared values and institutions. Writing in Le Monde in the immediate aftermath of the referendum, President Nicholas Sarkozy (2009) cautioned against criticism of the Swiss electorate by contending that 'Les peuples d'Europe sont accueillants, sont tolérants, c'est dans leur nature et dans leur culture' ('The people of Europe are welcoming, are tolerant, it's in their nature and in their culture'). Here, Sarkozy not only rehearses the scalar shift to a mediating Europeanness in the face of national, political complexities, but also the 'limits of tolerance'. Essentially tolerant, Europeans can be moved to intolerant 
measures - prohibitive and performative preconditions, for example - only by practices and people who are intolerable.

The intolerable - the figurative Muslim, the dis-int egrated migrant - are both the proof of civilization and a tear in its fabric, a disjuncture that energizes the current project of corrective integration. The limits of tolerance border a sociopolitical space in which exceptional measures of scrut iny, regulation and discipline become reasonable. 'Liberal tolerance discourse', in Wendy Brown's analysis, has a regulatory function, identifying 'both tolerance and the tolerable' within the West. Tolerance, like multicultural recognition, is dispensed from positions of assumed neutral ity, concealing how both the 'conceit of secularism' and liberalism's vision of a de-cultured, individualized, rational subject mark certain cultural and religious collectivities as undeserving of tolerance (Brown, 2006). The European insistence that 'limits need to be laid down' and the conditions of tolerated belonging reordered - with superstitions 'mocked' (see Malik, 2009), headscarves declared unwelcome, minarets prohibited if only to 'future-proof' European societies - is not seen as exclusionary. Given the critical gap between European surety and 'migrant' dis-integratedness, the insistence on integration is not just a question of securing cohesion against the threat of terror and unruly diversity, it is seen as a civilizing mission. Hence what looks like an assault on religious freedom through the minaret ban is no such thing: according to Ayaan Hirsi Ali, in a syndicated comment piece shaped by the recitation of what Baukje Prins terms a discourse of 'new realism' in post-multicultural Dutch discourse, the ban is a vote for tolerance and inclusion (Hirsi Ali, 2009; Prins, 2006).

These binaries are stark - clay pigeons racked for deconstruction - and paradoxically, they imagine the very 'parallel societies' that they fear. There is little inbetween, bar rhetorically produced 'moderate Muslims' propelled along a slide rule of progress, towards reason and away from extremism. In the contributions in this issue, these exaggerated lines of immutable division are shown to ignore the messy admixture of European societies, and the alternative social and political-economic explanations that complicate this picture of fundamental conflict. However, as these contributions also maintain, counter-strategies based on empirical evidence, the pedagogic 'fact' of hybridity and the need for intercultural dialogue frequently neglect that this binary 'stickiness' is shaped by the deep grammar of assemblage, and the racial arrangements and engagements that precede them. A proper understanding of the mediation of crisis requires a reconsideration of racism or, more specifically, the simultaneous mobilization and disavowal of 'race'.

\section{Racism and culturalism}

Multiculturalism, paradoxically, has provided a hegemonic language for discussing difference when 'race' is taboo. In his Reflections, Christopher Caldwell (2009) explicitly heads off any accusations of racism by reference to the language of culture and ethnicity. Discussing Spain's policy of 'ethnic filtering' - recruiting migrant labour from Latin America-Caldwell writes:

[This] is not racist. Spain is less concerned that its immigrants be white than that they have similarities of worldview with the people already established there, starting with knowing what the inside of a church looks like. (2009: 52) 
For Caldwell, 'race' and racism are exclusively linked to skin colour, and experiencing discrimination on apparently immutable cultural grounds is not to be confronted with racism. This commonsense reduction of racism to skin colour, coupled with the sheer impoliteness of the charge of racism, as Ghassan Hage (2003) has pointed out, has nothing to say about the experience of racial discrimination because the reordering in question is purely cultural. For Caldwell this is commonsense: cultures are incompatible; races, at least officially, do not exist - hence, neither does racism. Post-racialism is the dominant mode in which racism finds discursive expression in an era of cultural crisis, and unpacking this requires examining how 'race' and racism and culture and culturalism have become intertwined and sometimes interchangeable. The hegemony of culture as an over-determining explanatory frame is rooted historically in the ascent of 'race' as a political idea. The culturalization of politics identifiable today, of which the multicultural ism-integration axis is symptomatic, bears similarities to the idea that 'race is all' that came to dominate European politics in the 19th century (Hannaford, 1996). In an era of crisis, culture is all: like 'race', removing the domain of political contestation and constraining the terms of debate to a register that takes reified culture - both 'theirs' and 'ours' - for granted. Viewed from a historicized perspective that refuses the analytic separation between 'race' and culture, the apparently paradoxical cultura lism arrayed in opposition to mult iculturalism becomes more coherent. Understood biologically, 'race' is a category error that the West has resolved. Culture, post-race, is elevated ontologically while race-thinking remains immanent.

The roots of this excision are to be found in the early post-war period, when the horrors committed in the name of 'race' - the Nazi Holocaust - were revealed (Lentin, 2004). 'Race' was relegated to history as a faulty experiment resulting from bad science, thus to continue to espouse racist ideas was expressing an individualized pathology irrationally. As Goldberg (2002) makes clear, the problem with this view of 'race' is that it is associated exclusively with the Holocaust in Europe and slavery in the USA. Once these eras have passed and the mea culpas recited, it is possible to return to being 'race-free' (Goldberg, 2002). However, there is no such 'race'-free age to which to return, because racism is not bound exclusively to specific regimes such as Nazism or apartheid, no matter how acute an example of organized state racism they undoubtedly are. 'Race' is a product of modernity, rising in tandem with the nation-state (Balibar, 1991; Bauman, 1989) and the expansion of capitalism and colonialism (Winant, 2004).

The refusal to acknowledge the centrality of 'race' to modern political formation did not conflict with the belief, following the Holocaust, that it was nec essary to combat racism by reforming manifest human differences with reference to culture, cultural differences and problems of ethnocentrism. However, by not naming 'race' because, in essence, it would be racist to do so, influential thinkers such as Claude Lévi-Strauss (1961), who was involved in the UNESCO project on 'race' and racism, were in fact denying both the significance of racism in the lived experience of millions of people and the persistence of the racism embedded in institutions that did not change simply because the word 'race' could no longer be uttered. The difference here is between what Goldberg (2009: 10) calls antiracial ism: 'to take a stand ... against a concept, a name, a category, categorizing [which] does not itself involve standing (up) against (a set of) conditions of being or living' and anti-racism. In contrast, anti-racism does mean standing up to those conditions. While culturalist racism is not new (Stolcke, 1995; Taguieff, 1991), the move to delineate a break 
between 'old' biological racism and 'new' cultural racism has contributed unwittingly to a vision of racelessness in which racism is, de facto, impossible. As Howard Winant argues, 'the meaning of race is constantly being remade by human beings over historical time. So race is a sociohistorical construct' (2004: xviii). Thus, as Étienne Balibar (1991) has traced, modern racism has always been adaptive, historically merging biological and culturalist arguments to sustain and systematize immutable differences between groups of human beings in racially organized political systems.

If 'race' and culture as political ideas are inseparable, the current hegemony of culture has much to do with the pervasive tendency to frame the problem of difference and its solutions in cultural terms. In this regard, when conservative and liberal arguments describe multiculturalism as having 'gone too far', what they also have in mind is the range of prescriptive multicultural policies adopted by Western European governments, in different stages and to different extents, between the late 1960s and the 1990s. In this recitation, multiculturalism was a product of minority demands for cultural recognition, and elite political implementation of a project of cultural relativism and favouritism, that relativized national culture and universal liberal values simultaneously. What this narrative neglects is that anti-racist activists have always regarded the politics of cultural recognition as suspect. For the sake of brevity in introduction, it is worth recalling Paul Gilroy's (1987) by-now classic and once contemporaneous critique of the development of multiculturalist policies in Britain. As an attempt to appease and manage sociopolitical unrest, local government, in conjunction with 'community representatives', institutionalized an understanding of the discrimination experienced by a second generation as cultural: i.e. as a question of recognition and respect for cultural difference and expressive autonomy - asserting that it was 'here to stay' (Kundnani, 2007; Malik, 2009).

Across the West, policies aiming to take ethnic minorities under the state's wing - a step forward from seeing immigrants as temporary guest workers soon to return home extinguished the fires of dissent lit by a generation coming to political consciousness in the 1980s. Rarely recalled, the origins of state-sponsored multiculturalism allow us to trace the ways in which the problem of difference and differ ential treatment remains approached primarily as aquestion of cultural appreciation and discipline. As Maria Stehle documents in her discussion of Nersin, a young Turkish-German rapper and street fighter, both 'where did you leave your headscarf' and 'the interculturals' are regarded as modes of making her feel 'weak'. Similarly, in this issue, Ronit Lentin examines how significant inward migration to Ireland from the late 1990s was met by ablizzard of modes of cultural management, most particularly the mediation of an integrative notion of 'interculturalism' based on a rejection of European multicultural relativism. As Lentin argues, despite this insistence of having 'learnt from elsewhere' and refined a new approach, symbolic controversies soon revealed interculturalism as a vehicle for predictable forms of corrective integrationism. Ironically, in systemically obliging migrant groups to adopt the language of interculturalism and organize themselves through 'recognizable' community forms, 'Third Way' interculturalism transposed the essentialist micro-feudalism so central to the visions of multiculturalism that it was shaped to surpass.

The rapid culturalization of Irish responses to migration represents another example of what Sara Ahmed (2008) has termed the 'anti-performativity' of diversity and multiculturalist policies: that is, articulations that do not bring into being what they name. 
Instead, they may contribute to a "fantasy which conceals forms of racism, violence and inequality, as if the organization/nation can now say: how can you experience racism when we are committed to diversity?' (2008: 2). It is this disjuncture, between the experience of racism in the contemporary political-economic moment and the widely mediated celebration of moderate diversity or correction of aberrant diversity, that haunts the broad church of anti-racism. Official anti-racialism - including the 'unhelpful' idea of racism coexists comfortably with the current political problematization of lived multiculture, or what David Goodhart (2004) proposed was the problem of 'too much diversity'. Inscribed in a discourse of racelessness and a geopolitical context in which civilizational difference is ascribed central explanatory power, the contemporary themes of Muslim or immigrant separateness and dis-integrating difference are manifestations of established racial politics that blame the different and the marginalized, not only for the problems that they face, but the problems of society at large.

With anti-racialism and its stand against a proscribed concept comes the corollary that to discuss racism is at best to politicize debate, and at worst an attempt to shut it down. Where everyone has culture but some cultures have been shown to be unworthy of relativist parity, 'open debates' on the culturally intolerable can no longer be hostage to the politically correct charge of racism. Of course, this is both a political move and precisely the kind of discursive closure to which political correctness is routinely related. Because the language of 'race' and racism has been abandoned for that of different and nominally equal cultures, the terms of reordering fail to incorporate both the experience of racism and the struggle for equality and justice that anti-racism involves. It is this that enables the Right and liberals alike to base resurgent ideas of hierarchy and practices of coercive civilization on the fact of being post-race.

\section{Conclusion}

\section{The crisis of (multi)culturalism}

If we are not post-race, neither are we post-multicultural, despite the persistence of backlash. The rejection of something called multiculturalism in favour of varying forms of assimilationist integration projects marks a recalibration of multiculturalist ontology. While the populist Right, as discussed by Peter Hervik, explicitly demands the reconstruction of snug overlaps of territory, racial state and national culture, Kundnani and De Leeuw and Van Wichelen examine how multicultural backlash in the Netherlands and the UK has been largely driven by a nationalism articulated not through romantic tropes of heritage and lineage, but through claiming liberal values as a cohering leitkultur of minimum expectations. Cultural preconditions and prohibitions, in this context, have a governmental drive in attempts to engineer correct behaviours and acceptable subject-positions, or at least to be seen to attempt to do so.

For several contributors, the attraction of symbolic controversy and the concomitant drive to prescribe and proscribe correct modes of cultural recognition can be read as symptomatic of wider forms of anxiety. In these arguments the influence of Arjun Appadurai's (2006) work on the compensatory and often fantastical appeal of culture, in an era of political-economic instability and relative post-sovereignty, is apparent. The 
mobilities and immobilities of globalization produce lines of conflict between everyday experiences of uncertainty and the 'anxiety of incompleteness' that haunts the nation-state. Building on the kind of analysis advanced by Fekete (2009) for the 'mainstreaming' of xenophobia in the 1990s, Appadurai regards the

cultural field as the main one in which fantasies of purity, authenticity, borders and security can be enacted $\ldots$ the nation-state has been steadily reduced to the fiction of its ethnos as the last cultural resource over which it may exercise full dominion. (2006: 23)

The intolerable mediate these anxieties, positioned at the resolute borders of the cultural field and as a promise of reordering through discipline. This promise of cultural peace, as Michael Cronin discusses, both over-determines grounded interests, political differences and structural tensions as cultural, but in so doing, denies the vital agonism of politics and the 'ontological necessity of conflict' in unequal societies constituted by difference. Channelled through symbolic controversy, both the nationalist and liberal project to defend 'our way of life' reveal the final dimension of mediation at work in the 'crisis of multiculturalism': the reduction of multiple lines of conflict and uncertainty to questions of cultural incompatibility, and the calcification of political responses and possibilities to compensatory demands for allegiance and loyalty.

\section{Funding}

This research received no specific grant from any fund ing agency in the public, commercial or notfor profit sectors.

\section{Acknowledgements}

The symposium 'Questioning the European Crisis of Multiculturalism' was held at the National University of Ireland, Maynooth in December 2008. The guest editors would like to acknowledge the support of the dean of research at the National University of Ireland, Maynooth.

\section{Notes}

1. Caldwell's book is referenced regularly in this article because of the prominent transnational media coverage it received in 2009.

2. See Foulkes (2007) for coverage of the 'create security' posters that featured black sheep being kicked off the Swiss flag by white sheep. This image presaged the referendum poster featuring missile-like black minarets on the Swiss flag (BBC News, 2009).

3. Pipes' sources for the polls and surveys can be found in Pipes (2009).

\section{References}

Ahmed S (2008) Liberal multiculturalism is the hegemony. It's an empirical fact - a response to SlavojŽižek. Darkmatter: Post-colonial Futures, 18 February. Available at: www.darkmatter1 010. org/site/2008/02/19 (accessed 15 March 2008).

Appadurai A (2006) Fear of Small Numbers. An Essay on the Geography of Anger. Durham, NC: Duke University Press.

Applebaum A (2010) Don't blame the Swiss. Slate, 7 December. Available at: www.slate.com/ id/2237635 (accessed 19 January 2010). 
Badiou A (2008) The Meaning of Sarkozy. London: Verso.

Balibar E (1991) Is there a neo-racism? In: Balibar E and Wallerstein I, Race, Nation, Class: Ambiguous Identities. London: Verso, pp.37-67.

Bauman Z (1989) Modernity and the Holocaust. Cambridge: Polity Press.

BBC News (2009) Zurich allows anti-minaret poster. Available at: http://news.bbc.co.uk/2/hi/ europe/8297826.stm (accessed 29 November 2011).

Boe C and Hervik P (2008) Integration through insult? In: Eide E, Kunelius R and Phillips A (eds) Transnational Media Events. The Mohammed Cartoons and the Imagined Clash of Civilizations. Göteborg: Nordicom, pp.213-234.

Bohlen C (2009) Minaret threat eclipsed by Swiss intolerance. Bloomberg, 7 December. Available at: www.bloomberg.com/apps/news?pid $=20601039 \&$ sid $=\mathrm{a} 6 \mathrm{kHZEW}$ w $7 \mathrm{yCo}(\operatorname{accessed} 10$ January 2010).

Brown W (2006) Regulating Aversion: Tolerance in the Age of Identity and Empire. Princeton, NJ: Princeton University Press.

Caldwell C (2009) Reflections on the Revolution in Europe. London: Penguin.

Campbell M (2009) Women lead Swiss in vote to ban minarets. Available at: http:/islamizationwatch. blogspot.com/2009/11/women-lead-swiss-in-vote-to-ban.html (accessed 29 November 2011).

Crouch C (2004) Post-Democracy. Cambridge: Polity Press.

De Certeau M (1986) The Practice of Everyday Life. London: Routledge.

Eide E, Kunelius R and Phillips A (eds) (2008) Transnational Media Events. The Mohammed Cartoons and the Imagined Clash of Civilizations. Göteborg: Nordicom.

Fekete L (2009) A Suitable Enemy. Racism, Migration and Islamophobia in Europe. London: Pluto Press.

Fenton N (ed.) (2009) New Media, Old News. London: Sage.

Foulkes I (2007) Swiss row over black sheep poster. BBC News, 6 September. Available at: http:// news.bbc.co.uk/2/hi/europe/6980766.stm (accessed 29 November 2011).

Gilroy P (1987) There Ain't No Black in the Union Jack. London: Rout ledge.

Goldberg DT (2009) The Threat of Race. Reflections on Racial Neoliberalism. Oxford: WileyBlackwell.

Goldberg DT (2002) The Racial State. Oxford: Blackwell.

Goodhart D (2004) Too Diverse?, Prospect 95, February. Available at: www.prospectmagazine. co.uk/2004/02/too-diverse-david-goodhart-multiculturalism-britain-immigration-globalisation/ (accessed 12 January 2010)

Göle N (2010) Mute symbols of Islam. The Immanent Frame, 13 January. Available at: http://blogs. ssrc.org/tif/2010/01/13/mute-symbols-of-islam-and-their-resonance-in-european-public-space/ (accessed 12 January 2010).

Gregory D (2004) The Colonial Present. Oxford: Blackwell.

Gunew S (2004) Haunted Nations: The Colonial Dimensions of Multiculturalisms. London: Routledge.

Hage G (2003) Against Paranoid Nationalism. Searching for Hope in a Shrinking Society. Sydney: Pluto Press.

Hannaford I (1996) Race: The history of an Idea in the West. Baltimore, MD: Johns Hopkins University Press.

Hirsi Ali A (2009) Swiss ban on minarets was a vote for tolerance and inclusion. Christian Science Monitor, 5 December. Available at: www.csmonitor.com/Commentary/Opinion/2009/1205/ p09s01-coop.html (accessed 12 January 2010).

Judt T (2009) Reappraisals: Reflections on the Forgotten Twentieth Century. London: Vintage Books. Kundnani A (2007) The End of Tolerance. Racism in 21st Century Britain. London: Pluto Press. Lentin A (2004) Racism and Anti-Racism in Europe. London: Pluto Press. 
Lévi-Strauss C (1961) Race et histoire. Paris: Editions Gonthier.

Livingstone S (2009) On the mediation of everything. Journal of Communication 59(1): 1-19.

MacMaster N (2001) Racism in Europe. Basingstoke: Palgrave.

McGhee D (2008) The End of Multiculturalism? Terrorism, Integration and Human Rights. Buckingham: Open University Press.

Malik K (2009) From Fatwa to Jihad. The Rushdie Affair and its Legacy. London: Atlantic Books.

Mills CW (2007) Multiculturalism as/and/or anti-racism. In: Laden AS and Owen D (eds) Multiculturalism and Political Theory. Cambridge: Cambridge University Press, pp.89-114.

Mishra P (2009) A culture of fear. The Guardian Books, 15 August. Available at: www.guardian.co.uk/ books/2009/aug/1 5/eurabia-islamophobia-europe-colon ised-muslims (accessed 20 January 2010).

Nossek H (2007) 'Our news and their news': The role of national identity in the coverage of foreign news. In: Nossek H, Sreberny A and Sonwalkar P (eds) Media and Political Violence. Cresskill, NJ: Hampton Press, pp.1-19.

Phillips A (2007) Multiculturalism without Culture. Princeton, NJ: Princeton University Press.

Pipes D (2009) Swiss minarets and European Islam, 9 December. Available at: www.danielpipes. org/7808/swiss-minarets-european-islam (accessed 4 January 2010).

Pipes D (2010) Lion's den: Resistance to Islamization. The Jerusalem Post, 9 December. Available at: www.jpost.com/Opinion/Article.aspx?id=162677 (accessed 29 November 2011).

Pitcher B (2009) The Politics of Multiculturalism: Race and Racism in Contemporary Britain. Basingstoke: Palgrave Macmillan.

Prins B (2006) How to face reality: Genres of discourse with in Dutch minorities research. Unpublished paper, University of Groningen. Available at: http://philosophy.eldoc.ub.rug.nl/root/2007/ Howtoface/ (accessed 29 November 2011).

Ramadan T (2009) My compatriots vote to ban minarets is fuelled by fear. The Guardian, 29 November. Available at: www.guardian.co.uk/commentisfree/belief/2009/nov/29/swiss-voteban-minarets-fear (accessed 18 January 2010).

Rieff D (2005) The dream of multiculturalism is over. International Herald Tribune, 23 August, 5.

Rose F (2006) Europe's politics of victimology. Blueprint Magazine, 17 May.

Sarkozy N (2009) Respecter ceux qui arrivent, respecter ceux qui accueillent. Le Monde, 8 December. Available at: www.lemonde.fr/idees/article/2009/12/08/m-sarkozy-respecter-ceux-quiarrivent-respecter-ceux-qui-accueillent_1277422 3232.html (accessed 9 January 2010).

Silverstone R (2007) Media and Morality. On the Rise of the Mediapolis. Cambridge: Polity Press.

Schuster L and Solomos J (2001) Introduction: Citizenship, multiculturalism, identity. Patterns of Prejudice 35(1): 3-12.

Schlesinger P (2009) A cosmopolitan temptation. In Salovaara-Moring I (ed.) Manufacturing Europe. Spaces of Democracy, Diversity and Communication. Göteborg: Nordicom, pp.67-78.

Stehle M (2006) Narrating the ghetto, narrating Europe: From Berlin, Kreuzberg to the Banlieues of Paris. Westminster Papers in Communication and Culture 3(3) 48-70.

Stolcke V (1995) Talking culture: New boundaries, new rhetorics of exclusion in Europe. Current Anthropology 36(1): 1-24.

Taguieff P-A (ed.) (1991) Face au racisme 1: Les moyens dagir. Paris: La Découverte.

Taylor C (1992) The politics of recognition. In: Gutmann A (ed.) Multiculturalism and the Politics of Recognition. Princeton, NJ: Princeton University Press, pp. 25-74.

Titley G (2009) Pleasing the crisis: Anxiety and recited multiculturalism in the European communicative space. In: Salovaara-Moring I (ed.) Manufacturing Europe. Spaces of Democracy, Diversity and Communication. Göteborg: Nordicom, 153-170.

Traynor I (2009) Swiss vote to ban construction of minarets. The Guardian, 29 November. Available at: www.guardian.co.uk/world/2009/nov/29/switzerland-bans-mosque-minarets (accessed 17 December 2010). 
Winant H (2004) The New Politics of Race. Globalism, Difference, Justice. Minneapolis, MN: Minnesota University Press.

Yúdice G (2003) The Expediency of Culture: Uses of Culture in the Global Era. Durham, NC: Duke University Press.

\section{Biographical notes}

Alana Lentin is Senior Lecturer in Sociology at the University of Sussex. She works on the critical theorisation of 'race', racism and anti-racism and has done extensive research into the contemporary politics of (im)migration and collective action for migrants rights. Her books are Racism and AntiRacism in Europe (Pluto Press, 2004), and Racism (One World, 2008). With Gavan Titley, she has written The Crises of Multiculturalism: Racism in a Neoliberal Age (Zed Books, 2011) and edited The Politics of Diversity in Europe (Council of Europe Publishing, 2008).

Gavan Titley is Lecturer in Media Studies at the National University of Ireland, Maynooth. He works on discourses of 'race', racism and anti-racism, migration and media networks, the politics of migration in Ireland and Europe and the mediatization of crisis politics. His books include Broadcasting in the New Ireland (NUIM/BAI, 2010) Resituating Culture (editor, Council of Europe Publishing, 2004) and with Alana Lentin, The Crises of Multiculturalism: Racism in a Neoliberal Age (Zed Books, 2011) and The Politics of Diversity in Europe (co-editor, Council of Europe Publishing, 2008). 